\title{
A New Anthracocystis (Ustilaginales) Record for Turkey
}

\section{Türkiye için Yeni Bir Anthracocystis (Ustilaginales) Kaydı.}

\section{Research Article}

Şanlı Kabaktepe ${ }^{*}$, llgaz Akata², Hasan Akgül ${ }^{3}$

IInonu University, Battalgazi Vocational School, Battalgazi, Malatya, Turkey.

${ }^{2}$ Ankara University, Faculty of Science, Deparment of Biology, Ankara, Turkey.

${ }^{3}$ AkdenizUniversity, Faculty of Science, Department of Biology, Antalya, Turkey.

\section{A B S TR AC T}

smut species, Anthracocystis penniseti (Rabenh.) McTaggart \& R.G. Shivas (Ustilaginaceae) on Pennisetum orientale Rich. (Poaceae) is reported for the first time from Turkey. The morphological and microscopical features of this fungi are described with figures.

\section{Key Words}

Kayseri, Mersin, New records, Ustilaginales.

\section{ÖZET}

ir rastık mantarı türü Anthracocystis penniseti (Rabenh.) McTaggart \& R.G. Shivas (Ustilaginaceae) Pennisetum orientale Rich. (Poaceae) bitkisi üzerinde Türkiye'den ilk kez kaydedilmiştir. Bu mantarın şekilleri ile morfolojik ve mikroskobik özellikleri toplanan örneklere bağlı olarak tanımlanmıştır.

\section{Anahtar Kelimeler}

Kayseri, Mersin, Yeni kayıt, Ustilaginales.

Article History: Received: Dec 31, 2015; Revised: Feb 02, 2016; Accepted: Feb 03, 2016; Available Online: Apr $01,2016$.

DOI: $10.15671 /$ HJBC.20164417562

Correspondence to: Ş. Kabaktepe, Inonu University, Battalgazi Vocational School, Battalgazi, Malatya, Turkey. 


\section{INTRODUCTION}

After the rust fungi (Uredinales), the smut fungi are the second most important group of plant parasitic Basidiomycota. There are approximately 1200 smut species known that together can infect more than 4000 different plant species. Most of the smut fungi are recognized by the black or brown spore masses or sori forming in the inflorescences, the leaves, or the stems of their hosts. They develop usually dark, powdery masses of teliospores ("spores") in sori. The teliospores are liberated, dispersed, and germinate with basidia. After a more or less prolonged saprophytic stage, dikaryotic hyphae infect susceptible host plants [1].

Anthracocystis is a large genus of family Ustilaginaceae within the order Uredinales. The genus contains about 126 species in the world. The members of the genus are characterized by sori replacing inflorescences, all of the racemes or localized in spikelets of an inflorescence. Peridium of vacuolated fungal cells surrounded by a single layer of host cells. Columella composed of vascular bundles surrounded by host parenchyma permeated by inter- and intracellular hyphae, often separated into several columellae each around a vascular bundle surrounded by parenchyma, filiform, flexuous, flattened. Sporogenous hyphae coiled. Spores compacted in spore balls, globose to subglobose, often outer spores darker than inner spores. Sterile cells few or absent [2].

In the last decade, reports of new records of smut fungi have greatly increased in Turkey. According to current literature [3-11] approximately 59 smut species belonging to 9 genera have so far been reported from Turkey, but there is not any record of Anthracocystis penniseti (Rabenh.) McTaggart \& R.G. Shivas.

The purpose of the present study is to make a contribution to the Turkish smut mycobiota.

\section{MATERIALS AND METHODS}

Materials were collected in 2013 from Kayseri and Mersin provinces in Turkey. The host specimens were prepared according to established herbarium techniques. Host plants identified use the Flora of Turkey and the East Aegean Islands [12]. Spores were scraped from dried host specimens and mounted in lactophenol. Microphotographs were taken under a light microscope (Noveks B series 1000). Analysis LS Starterwas software was used to measure. Identification was performed with the aid of literature $[1,2]$. The identified samples are deposited in the Inönü University Herbarium (INU).

\section{RESULTS AND DISCUSSION}

Basidiomycota R.T. Moore

Ustilaginomycetes

Ustilaginales

Ustilaginaceae Tul. \& C. Tul.

Anthracocystis Bref.

Key to species of Anthracocystis on Pennisetum

1.Sorirestricted totheovaries .2

1.*Sorinotrestricted totheovaries...............................3

2. Columella one, shorth, spores smoo......... tothii 2.*Columella several, filiform, spores verruculose.. A. ehrenbergii

3.Soridestroying the wholeinflorescensoronthetop of the sterile shoot. . .4

3.*Sori restricted to the spikelets..........A. penniseti 4.Soridestroyingthe wholeinflorescens..................5 4.*Sori destroying on the top of the sterile shoot A. cenchri

5. Spores dimorfic. pennisetina

5.*Spores not dimorfic. A. penniseticola

6. Spores irregular, wall even. A. sphacelata

Anthracocystis penniseti (Rabenh.) McTaggart \& R.G. Shivas (Figure 1).

Sori in all spikelets of an inflorescence, cylindrical, 1-1.5 $\times$ 2-7 $\mathrm{mm}$, hidden by the outer floral envelopes, covered by a greyish brown peridium which flakes away exposing the semiagglutinated to granular-powdery mass of spore balls and a central columella of the length of the sori, with a few, short, apical branches. Spore balls globose, ovoid to ellipsoidal, 40-110 $\mu \mathrm{m}$ long, dark reddish brown, composed of many spores that separate rather easily. Spores dimorphic. Outer spores globose to ellipsoidal, 9-15×(9-) 


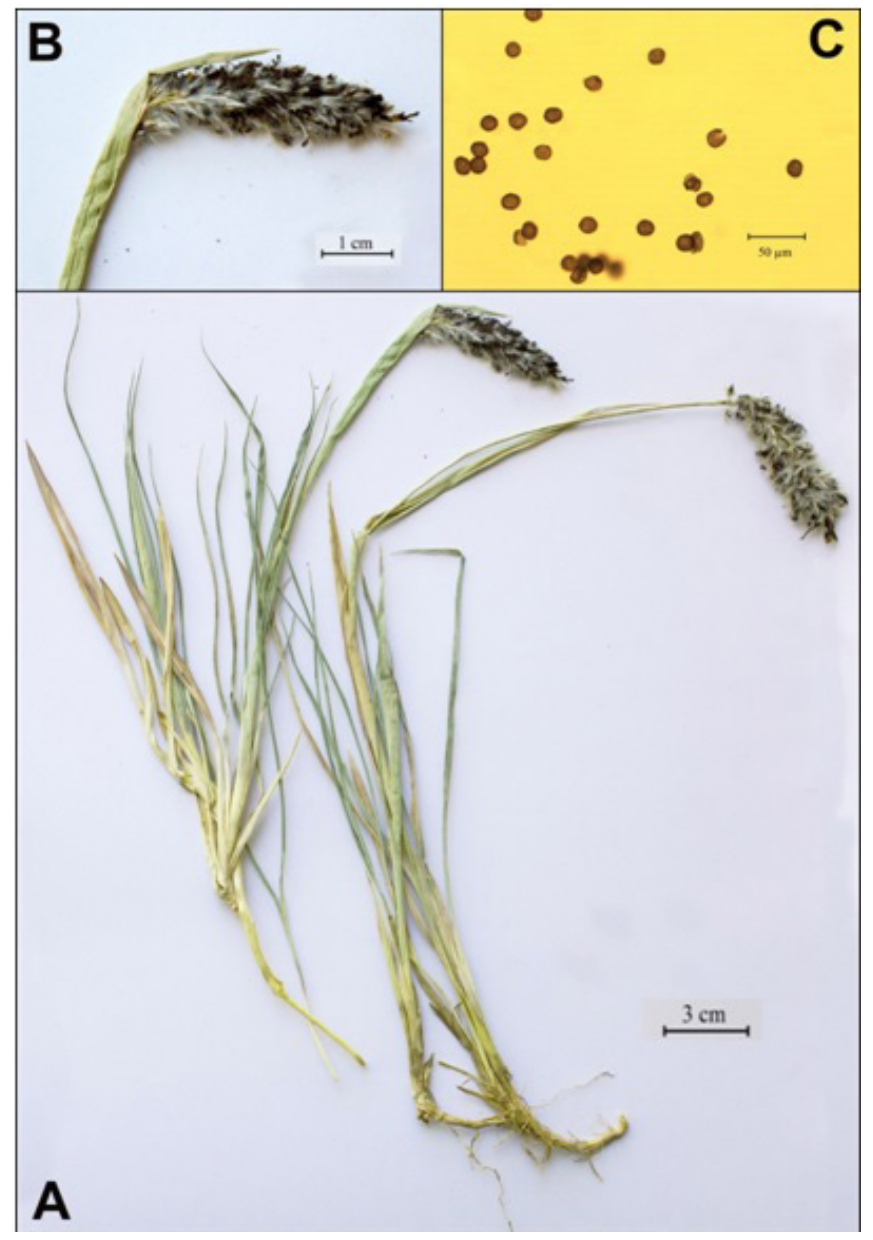

Figure 1. Anthracocystis penniseti A. dried herbarium specimen, B. SM view of Anthracocystis penniseti on sori, C. LM view of Teleutospores.

10-13.5(-14.5) $\mu \mathrm{m}$, medium reddish brown, finely and densely echinulate. Inner spores subpolyhedral, smaller (7-10 $\mu \mathrm{m})$, paler coloured and finely punctate or apparently smooth. Spore germination results in 2 -celled basidia, each cell producing a long, ramifying hypha.

Specimens examined-On Pennisetum orientale Rich. (Poaceae): TURKEY-Kayseri, Yahyalı, Ilyasli Village, 1250-1400 m, 26.06.2013, S. Kabaktepe 7185 (INU 1201); TURKEY-Mersin, Tarsus, Gulek village, 1240 m, 08.10.2013, Ş. Kabaktepe 7318 (1202).

Remarks: Anthracocystis penniseti is easly distinguished from other Anthracocystis species by its restricted to the spikelets, one columella and 9-15 $\mu \mathrm{m}$ long spores. It is a cosmopolite species on Cenchrus L. and Pennisetum Rich. (Poaceae) host genera [1,2]. It is also reported on Pennisetum orientale from Iran and Israel $[13,14]$.

According to literature $[1,2]$, nine confirmed species on Pennisetum sp. (A. cenchri (Rabenh.) McTaggart \& R.G. Shivas, A. ehrenbergii (Rabenh.) McTaggart \& R.G. Shivas, A. penniseti (Rabenh.) McTaggart \& R.G. Shivas, A. penniseticola (Vánky) McTaggart \& R.G. Shivas, A. pennisetina (Vánky) McTaggart \& R.G. Shivas, A. sphacelata (Vánky) McTaggart \& R.G. Shivas, A. tothii (Vánky) McTaggart \& R.G. Shivas) currently exist in the genus Anthracocystis. But only Anthracocystis ehrenbergii (J.G. Kühn) McTaggart \& R.G. Shivas on Sorghum bicolor (L.) Moench has previously been reported from Turkey [9]. 
With the current study, Anthracocystis pennise$t i$ is reported for the first time from Turkey and the number of Turkish smut fungi species will increase approximately to 60 .

\section{ACKNOWLEDGEMENTS}

This study was supported by TUBITAK (Project no: 113z093).

\section{References}

1. K. Vánky, Smut Fungi of the World. APS press. St. Paul., Minnesota, 2012.

2. A.R. McTaggart, R.G. Shivas, A.D.W. Geering, K. Vanky, T. Scharaschkin, Taxonomic revision of Ustilago, Sporisorium and Macalpinomyces. Persoonia, 29 (2012) 116-132.

3. Z. Bahcecioglu, B.Yildiz, A study on the microfungi of Sivas Province. Turkish J. Bot., 29 (2005) 23-44.

4. Z. Bahcecioglu, S. Kabaktepe, B. Yildiz, Microfungi isolated from plants in Kahramanmaras Province, Turkey. Turkish J. Bot., 30 (2006) 419-434.
5. S. Kabaktepe, Z. Bahcecioglu, Microfungi identified from the flora of Ordu Province in Turkey. Turkish J. Bot., 30 (2006) 251-265.

6. S. Kabaktepe, Z. Bahcecioglu, New Anthracoidea, Tilletia, and Ustilago records for Turkey, Mycotaxon, 122 (2012) 283-285.

7. S. Kirbag, Two new records for the mycoflora of Turkey, Turkish J. Bot., 27 (2003) 153-154.

8. F. Petrak, Neue Beiträge zur Pilzflora der Türkei, Sydowia, 7 (1953) 14-15.

9. N. Sahin, A.U. Tamer, Smut species determined in Turkey, J. Turk. Phytopath., 27 (1998) 151-156.

10. H.B. Sert, Additions to rust and smut fungi of Turkey, Phytoparasitica, 37 (2009) 189-192.

11. H.B. Sert, H. Sumbul, M. Isiloglu, Phytopathogenic fungi new for Southern Anatolia, Turkey, Phytoparasitica, 32 (2004) 402-408.

12. H. Scholz, Pennisetum Rich., In: P.H. Davis, editor. Flora of Turkey and the East Aegean Islands. Edinburgh University Press, Vol 9: 601. Edinburgh University Press, Edinburgh, 1985.

13. K. Vanky, M. Abbasi, Smut fungi of Iran, Mycosphere, 4 (2013) 363-454.

14. K.G. Savchenko, V.P. Heluta, S.P. Wasser, E. Nevo, Smut fungi of Israel: A preliminary check-list, Mycol. Balcan., 7 (2010) 111-116. 